\title{
UPDATED EDUCATIONAL CURICULUM FOR ENGLISH LANGUAGE LESSONS IN KAZAKHSTAN
}

\author{
Yelena Ivanuna ${ }^{1}$, Elmira Uteubayeva ${ }^{2}$, Dilyana Arsova ${ }^{3,4}$ \\ ${ }^{1}$ E.A. Buketov Karaganda University, Karaganda, Kazakhstan \\ ${ }^{2}$ E.A. Buketov Karaganda University, Karaganda, Kazakhstan \\ ${ }^{3}$ St. Cyril and St.Methodius University of Veliko Tarnovo, Bulgaria \\ ${ }^{4}$ SU ,,Tsanko Tserkovski“, Polski Trambesh, Bulgaria
}

\author{
ORCID iD: 0000-0002-1648-114X
}

\begin{abstract}
In the 2016-2017 academic year, an update of the education system and its content was introduced in Kazakhstan. Updating the content of education in the Republic of Kazakhstan sets itself the main goal - improving the pedagogical skills of teachers in the context of updating the educational program and introducing a system of criteria-based assessment. The article discusses the features of the updated content of education in the Republic of Kazakhstan, containing aspects of building knowledge acquisition based on Bloom's taxonomy. Here we have discussed: the details of taxonomy levels; a new structure of educational programs; the main differences from previous versions of educational programs compared to the updated version; criteria for assessing formative assessment; the tasks for the summative assessment of primary schoolchildren in English for the section and for the quarter; an example of a descriptor for assessing the mastery of knowledge in English lessons; the principle of the spiral approach in the preparation of programs within the framework of renewed education; the advantages of a training program using the spiral principle; Using the updated version, education should become competitive, high-quality, and, therefore, such that graduates of the Kazakh school can easily continue their studies in foreign universities.
\end{abstract}

\section{INTRODUCTION}

The content of education entails an adapted system of pedagogical scientific knowledge related to practical skills and abilities that their students must acquire [Sushchenko, Akhmedova, Stryzhak, 2021; Zagorodnya et al, 2020A; Zagorodnya et al, 2020B. The content of education is a pedagogically adapted social experience in all its structural completeness, consisting of four elements [Scriabina N.A.]:

1) the experience of cognitive activity, fixed in the form of results (about nature, technology, society, thinking);

2) experience in the implementation of known methods of activity - in the form of skills to act according to a model;

3) experience of creative activity - in the form of the ability to make non-standard decisions in problem situations (mastering the experimental technique, participation in artistic, technical and social creativity);

4) the experience of implementing emotionally valuable relationships - in the form of personal orientations (attitude to the world around, people, oneself, moral norms, ideological ideas, etc.)

In the context of the renewed primary education system, a qualitatively new, personal, developmental strategy for the education and upbringing of children is being implemented [Petrova, Popova, Dejniak, 2020; Spivak et al, 2021; Valdmane et al, 2020]. The most important priorities of which are [Dargevichiene, 2015]:

- a formation of knowledge, educational skills, skills, motivation and ability to learn in primary schoolchildren;

- a prevention of subject dissociation;

- an integration of academic disciplines for solving educational problems of schoolchildren; 
- an introduction of early learning of a foreign language by them, mastery of informative and information technology;

- a support and development of the child's personality, protection and strengthening of his physical and mental health.

\section{RESEARCH METHODS}

Here, the research methods such as were used: observation, self-observation, study, generalization and dissemination of mass and advanced pedagogical experience.

\section{RESULTS AND DISCUSSION}

Updating the content of education implies a transition from the traditional organization of the educational process, where, first of all, the content of education reflected in the curriculum was determined (while each of the developers tried to cover as much theoretical material as possible), and is based on the expected results, which are determined by educational areas and reflect an activity aspect using Bloom's tiered taxonomy. [Linde, Petrova, 2018; Chernukha et al, 2021; Diachok et al, 2020; Goletiani et al, 2021; Nenkov et al, 2016].

The first step is to identify a learning goal, to consider the importance of learning the topic, its place in the curriculum and its role in providing the knowledge base. The instructor should first establish key learning objectives that determine the behaviour of students after class. To stimulate critical thinking, these learning objectives, as well as activities and assessments, must include those associated with higher levels of Bloom's taxonomy [Crossland John, 2015].

A well-defined goal should include skills appropriate to the chosen taxonomy level.

The "Knowledge of Facts" level requires an answer that demonstrates simple recall of facts. Here the teacher can ask students to answer the questions "Who or What?", As well as describe the subject or object, list facts, arguments.

The "Comprehension" level requires a response that demonstrates understanding of the information. Questions at this level should be structured in such a way that students can generalize, explain, paraphrase, compare and contrast [Tuzlukova, Al-Busaidi \& Burns, 2017].

The "Analysis" level requires an answer that demonstrates the ability to see patterns and classify information, concepts, and theories into their component parts. Questions at this level can motivate students to learn, classify, differentiate, and analyse.

The "Application" level requires an answer that demonstrates the ability to use information, concepts and theories in new situations. Assignments at this level may ask students to apply, build, solve, discover, and show new possibilities.

At the "Assessment" level an answer is required to demonstrate the students' ability to judge evidences based on well-rounded reasoning. Items at this level may ask students to evaluate, criticize, recommend, predict, and evaluate something [Khmelnitskaya, 2008].

The "Synthesis" level requires an answer that demonstrates the ability to connect knowledge from multiple areas to generate new or original ideas. Problems at this level may challenge learners to combine, design, create, role-play, and guess.

The second step is to conduct a survey. This is an essential part of the learning process. The survey allows the teacher to ascertain what is already known and then expand on it to develop new ideas and understanding. Questions can be used to improve the interaction between teacher and student and to encourage the student to stand up for his or her position (i.e., think critically). Therefore, when a teacher plans a lesson, he should consider the purpose of each question and then develop the appropriate level and type of question to achieve the goal. All students need experience with higher level questions as they become familiar with the concept. To ensure this experience, careful preparation by the teacher is essential.

The third step involves anchoring in practice prior to the assessment. Since active teaching methods are more effective than passive ones, the reinforcement of the learned material works well when conducting experiments, building models, completing projects, etc. These techniques allow students to retain knowledge for longer. 
In the fourth step, where review, refinement, improvement takes place, teachers should strive to continually improve their lessons so that their teaching methods truly help students develop critical thinking skills. Thus, teachers must very closely monitor the activities of students in the classroom. To track student participation, a journal should be kept that records student activity, describes the main activities in the classroom, and evaluates student achievement. Other reflective comments can also be tracked in this journal and can be very helpful when revising or updating the learning assignments.

The final step is to provide feedback and assessment of the training. Teacher feedback, like assessment, compares criteria and standards with student performance in order to assess performance [Shuinshina, Alpeisov, Akhmetova, Tuyakov \& Adamova, 2019]. The purpose of feedback is to improve the quality of learning and student achievement, rather than to measure their progress, and importantly, they can help students learn to measure their own future performance. Feedback allows the teacher and students to engage in a dialogue about what separates good performance from bad grades, while discussing criteria and standard.

It can also be noted that a distinctive feature of the updated curricula is a new structure, which includes [Kokhaeva, 2014]:

1) the importance of the subject;

2) the objectives of the curriculum for the subject;

3) implementation of the policy of trilingualism;

4) organizational requirements for the process of teaching the subject;

5) pedagogical approaches to teaching the subject;

6) fostering respect for the diversity of cultures and opinions;

7) competence in the use of information and communication technologies;

8) development of students' communication skills;

9) approaches to assessing the results of studying the subject;

10) content, organization and sequence of sections of the program in the subject.

The aspects of the curriculum contain educational material by level of education. The curriculum is accompanied by an advisory curriculum, which consists of long-term and medium-term plans. The plan, based on a system of goals and approaches to teaching, provides recommendations for teachers on conducting classes on topics and sections, organizing students in lessons, and includes educational resources (Internet, texts, exercises, video and audio materials, etc.).

The updated curricula differ from the previous versions by the presence of:

- the principle of spiral to design the content of the subject;

- the hierarchy of learning objectives according to Bloom's taxonomy;

- the location of educational goals by levels throughout the entire course of study, which makes it possible to take into account the most of intra-subject connections;

- correspondence of the content of sections and subjects of subjects to modern trends of the current time, emphasis on the formation of social skills;

- long-term, medium-term, and short-term planning of the educational process.

In the context of the updated content about the subject of "English language", the communicative approach has been strengthened, which is aimed at developing four skills of speech activity: listening, speaking, reading and writing. Grammar is studied within the proposed conversational topics.

A positive feature in the study of English is the introduction of a single speech-thematic mode, which allows you to expand your vocabulary, practice communication skills within the framework of an integrated speech subject. Teaching in the subject "English" (as a second language) is carried out according to the CEFR (Common European Framework of Reference for Languages).

The updated program includes new textbooks, new strategies and methodological approaches in teaching, a new grid of hours, as well as a change in the content of education, a new vision of longterm, medium-term and short-term planning and new approaches to assessing children (formative, summative assessment). 
According to the updated program, two assessment criteria are used: formative and summative (Figure 1).

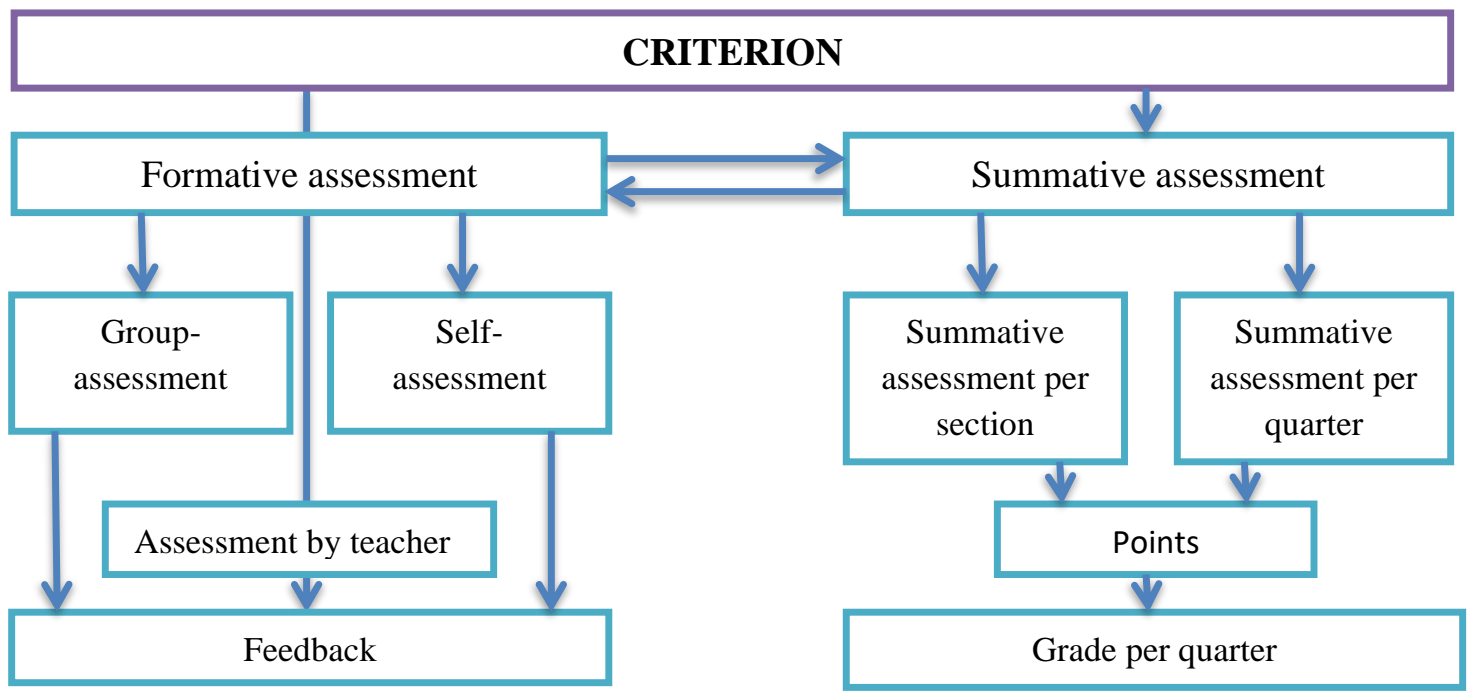

Figure 1. Evaluation criteria

For effective formative assessment, a learning goal, assessment criterion, tasks, descriptors, feedback are established (Figure 2).

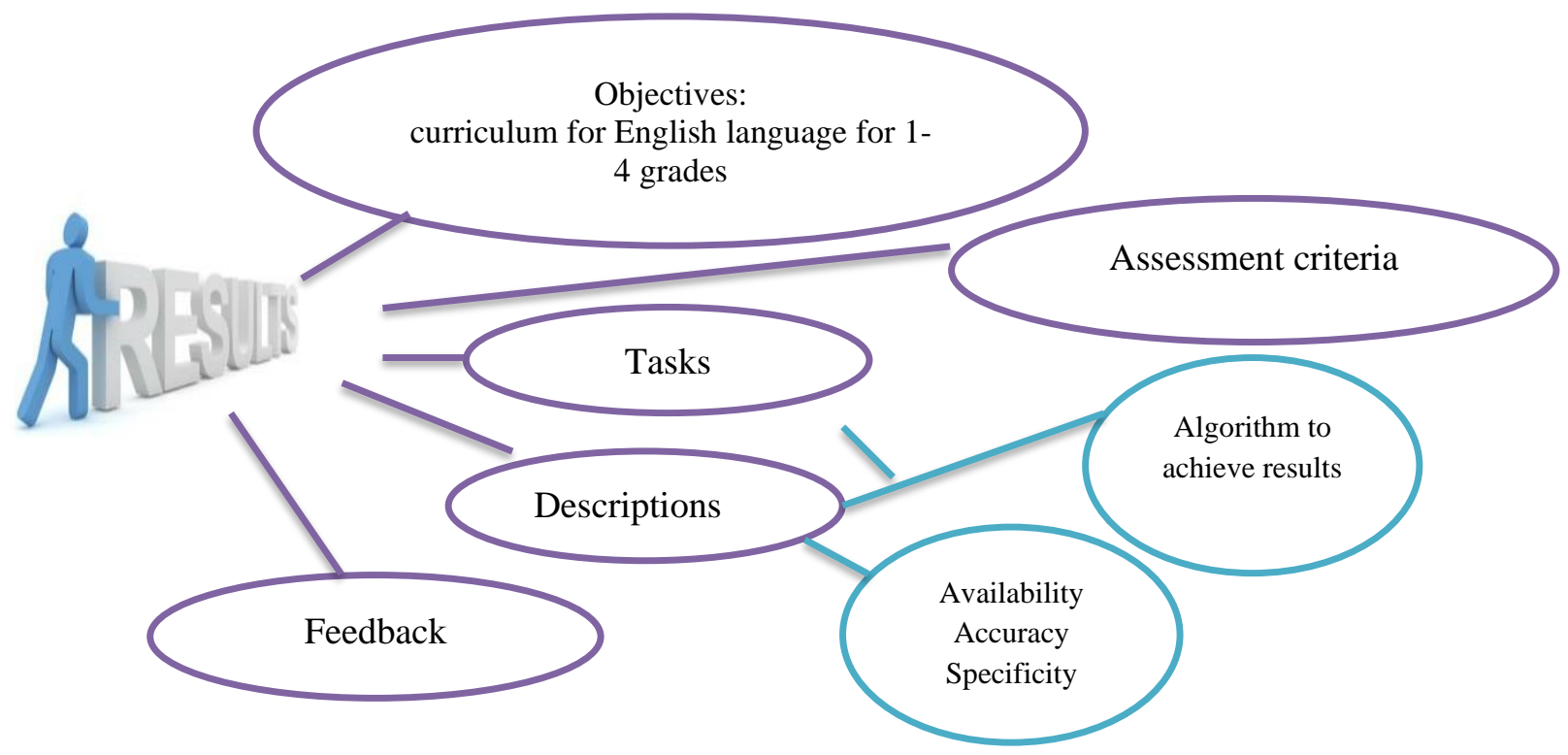

Figure 2. Formative assessment

Formative assessment is an ongoing process.

An example of a formative assignment for English subject in 1st quarter of grade 3 students is shown in Figure 3.

Formative assessment is focused on providing feedback when students perform specific tasks or actions in the lesson [Adekenova, Ustinova \& Adekenova, 2017]. 

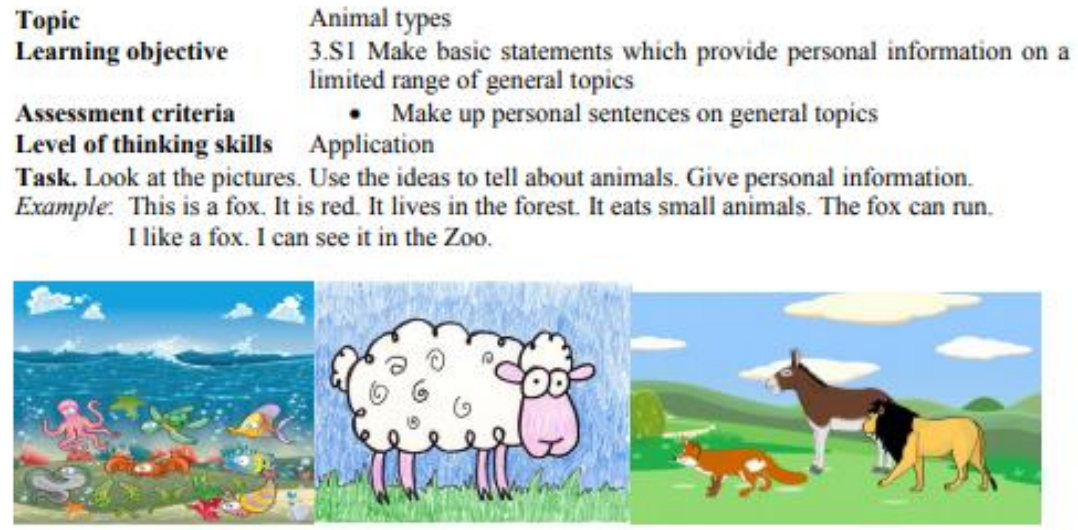

Descriptor:

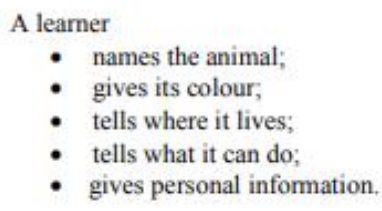

- gives its colour;

- tells where it lives;

- tells what it can do;

- gives personal information.

Figure 3. An example of a formative task

The summative work per section (SWS) is $50 \%$ of the total score. There are two such works per quarter. In the humanities, summative work is carried out within the framework of a cross-cutting theme. The teacher can choose the assessment tools on his own or make additions to the standard developments.

The Summative Quarter Grade (SOC) is $50 \%$ of the Quarter Grade. The summative work for a quarter takes 20 - 40 minutes, it involves carrying out various kinds of control and verification work. An example of a task for summative work for a quarter for grade 3 (Figure 4)

TERM 4

SUMMATIVE ASSESSMENT TASKS

Summative Assessment for the cross curricular unit «Water, water everywhere»

\begin{tabular}{|c|c|}
\hline Learning objectives & $\begin{array}{l}\text { 3.3.6.1 (3.R6) Understand with considerable support, some specific } \\
\text { information and detail in short, simple texts on a limited range of } \\
\text { general and some curricular topics } \\
\text { 3.2.5.1 (3.S5) Pronounce familiar words and short phrases intelligibly } \\
\text { when reading aloud }\end{array}$ \\
\hline Assessment criteria & $\begin{array}{l}\text { - Identify detailed information of simple texts on general and } \\
\text { curricular topics } \\
\text { - Articulate familiar words and short phrases intelligibly }\end{array}$ \\
\hline Level of thinking skills & $\begin{array}{l}\text { Knowledge and comprehension } \\
\text { Application }\end{array}$ \\
\hline Duration & 20 minutes \\
\hline \multicolumn{2}{|l|}{ Reading } \\
\hline \multicolumn{2}{|c|}{ Task 1. Read the text about Tommy and answer the questions. } \\
\hline \multicolumn{2}{|c|}{$\begin{array}{l}\text { Tommy drinks water every day. He also washes his face, brushes his teeth } \\
\text { and takes a shower every day. } \\
\text { On Monday, Tommy helps his father water the garden. On Tuesday, } \\
\text { Tommy and his mother cook dinner and wash dishes. On Wednesday, Tommy } \\
\text { helps his baby brother to bathe. His baby brother likes to play in the bath. }\end{array}$} \\
\hline \multicolumn{2}{|c|}{ 1. What does Tommy drink every day? } \\
\hline \multicolumn{2}{|c|}{ 2. What does Tommy do with his father? } \\
\hline \multicolumn{2}{|c|}{ 3. What does Tommy do on Tuesday? } \\
\hline \multicolumn{2}{|c|}{ 4. Where does Tommy's brother like to play? } \\
\hline \multicolumn{2}{|l|}{ Speaking } \\
\hline $\begin{array}{l}\text { Task 2. Read all the quest } \\
\text { Look at the pictur } \\
\text { 1. What is this? (teacher } \\
\text { 2. Where does it live? } \\
\text { 3. What colour is a dolphi } \\
\text { 4. Did you go to the beach } \\
\text { 5. What did you do at the } \\
\text { (Note for a teacher: if the } \\
\text { one-What is he/she doin }\end{array}$ & $\begin{array}{l}\text { ons aloud first and then answer them in full sentences. } \\
\text { s if you need some help. } \\
\text { ints to a sea animal) } \\
\text { ? } \\
\text { last summer? } \\
\text { each? } \\
\text { earner answers "no" to the previous question change it } \\
\text { ? Point at any person in the picture). }\end{array}$ \\
\hline
\end{tabular}



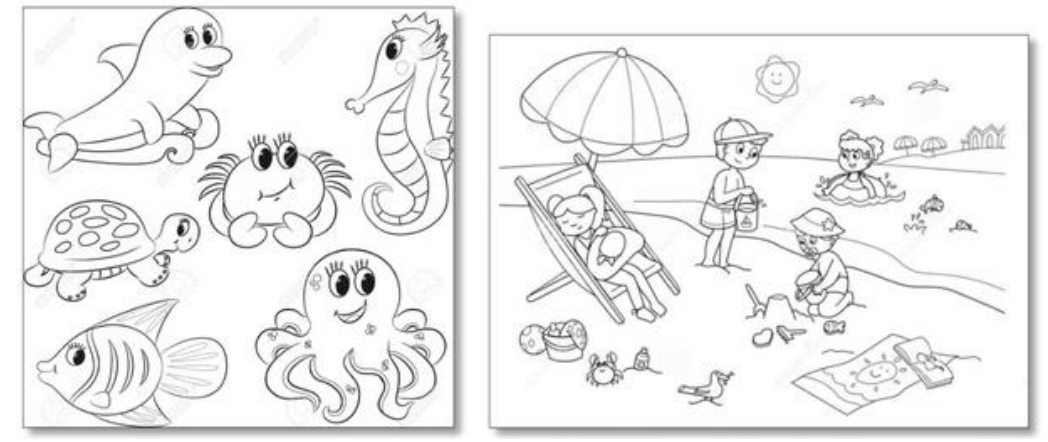

Figure 5. Summative work for a quarter for grade 3

Summative work per quarter includes multilevel tasks that should demonstrate the achievement at various skills, including checking the levels of thinking of a higher order: analysis, synthesis and assessment [Almagambetova, 2017].

As evaluation criteria, points are used according to the updated program, focusing on descriptors - a description of different levels of achievement of the expected result, moreover, the scale may be different. Table 1 shows an example of the SOC scoring by descriptors.

Table1 - Descriptions for SOC

\begin{tabular}{|c|c|c|c|c|}
\hline \multirow{2}{*}{$\begin{array}{l}\text { Assessment } \\
\text { criteria }\end{array}$} & \multirow{2}{*}{$\begin{array}{l}\text { Task } \\
\text { № }\end{array}$} & Descriptor & \multirow[t]{2}{*}{ Mark } & \multirow{2}{*}{$\begin{array}{l}\text { Additional } \\
\text { information }\end{array}$} \\
\hline & & A learner & & \\
\hline \multirow{4}{*}{$\begin{array}{l}\text { Identify detailed } \\
\text { information of } \\
\text { simple texts on } \\
\text { general and } \\
\text { curricular topics }\end{array}$} & \multirow[t]{4}{*}{1} & $\begin{array}{l}\text { 1. Answers 'Tommy/He drinks } \\
\text { water every day' }\end{array}$ & 1 & \multirow[t]{4}{*}{$\begin{array}{l}\text { Short } \\
\text { acceptable }\end{array}$} \\
\hline & & $\begin{array}{l}\text { 2. Answers 'Tommy helps his } \\
\text { father water the garden/On Monday, } \\
\text { Tommy helps his father water the } \\
\text { garden.' }\end{array}$ & 1 & \\
\hline & & $\begin{array}{l}\text { 3. Answers 'Tommy and his mother } \\
\text { cook dinner and wash dishes. /On } \\
\text { Tuesday, Tommy helps his mother } \\
\text { cook dinner and wash dishes.' }\end{array}$ & 1 & \\
\hline & & $\begin{array}{l}\text { 4. Answers 'Tommy's brother likes } \\
\text { to play in the bath. His brother likes } \\
\text { to play in the bath.' }\end{array}$ & 1 & \\
\hline \multirow{5}{*}{$\begin{array}{l}\text { Articulate } \\
\text { familiar words } \\
\text { and short phrases } \\
\text { intelligibly }\end{array}$} & \multirow[t]{5}{*}{2} & $\begin{array}{l}\text { Possible answers } \\
1 . \quad \text { This is a fish. }\end{array}$ & 1 & \multirow{5}{*}{$\begin{array}{l}\text { Other answers are also } \\
\text { acceptable if they } \\
\text { answer the questions in } \\
\text { accordance with the } \\
\text { pictures. } 1 \text { point for } \\
\text { each correct answer. }\end{array}$} \\
\hline & & $\begin{array}{l}2 . \quad \text { It lives in the } \\
\text { sea/river/ocean. }\end{array}$ & 1 & \\
\hline & & 3. A dolphin is grey and white. & 1 & \\
\hline & & $\begin{array}{l}\text { 4. Yes, I went to the beach last } \\
\text { summer/ No, I didn't go to the beach } \\
\text { last summer. }\end{array}$ & 1 & \\
\hline & & $\begin{array}{l}5 . \quad \text { I ate ice-cream at the } \\
\text { beach./She/ He is swimming. (The } \\
\text { verb and the pronoun depend on the } \\
\text { picture) }\end{array}$ & 1 & \\
\hline \multicolumn{3}{|l|}{ Total marks } & 9 & \\
\hline
\end{tabular}

A descriptor is a kind of instruction that allows the student to successfully complete an assignment. The descriptor is an algorithm for achieving success. 
As part of the updated program, CLIL (Content and Language Integrated Learning) is often used - it is more than watching how students work together with the teacher during the lesson, it is a change and constant modification of activities with a mixture of different methods and techniques.

The spiral principle of planning the content of the subject according to the updated curriculum allows you to expand the educational material vertically and horizontally to improve knowledge and skills (that is, increasing the complexity of knowledge by topics and classes).

Benefits of the spiral curriculum:

- application of previously acquired knowledge to achieve the goals of learning outlined by students;

- new knowledge is closely related to the previous one and is considered from the point of view of the information received;

- with each repetition, the complexity of the topic or subject increases;

- the spiral educational program allows you to move from simple ideas to more complex ones in a convenient way.

\section{CONCLUSION}

The structure of the updated content of education, considering planning and criteria-based assessment, should unfold in the context of the question: "Why study at school?", instead of the traditional question: "What to teach at school?". This is helped by the introduction of updated curricula, textbooks and handouts that allow students to effectively master certain skills in English lessons: listening, speaking, reading, and writing.

The task of the teacher in the updated curriculum is to determine and plan in advance what will be interesting and useful to each student, as well as to use techniques in the process of completing the assignment that will increase the activity and initiative of students.

\section{REFERENCES:}

Adekenova A.N., Ustinova L.V., Adekenova U. A. (2017) new model of assessment in the field of education of the Republic of Kazakhstan // Educational process, No. 2.

Almagambetova L.S. (2017) Monitoring the difficulties of teachers in understanding the content, methods, forms of organizing the educational process in the context of updating the content of education in the Republic of Kazakhstan // Educational process, No. 2.

Chernukha, N., Petrova, M., Vasylieva-Khalatnykova, M., Krupnyk, Z., Krasilova, Y. (2021). The role of the Sociocultural Environment of Inclusion in the Modern Educational Institution. International Journal of Higher Education, Vol. 10, No. 3, June 2021, p.211-222, https://doi.org/10.5430/ijhe.v10n3p211

Crossland John (2015) Thinking Skills and Bloom's Taxonomy // Primary science, No. 11,

Dargevichiene L.I. (2015) Actual problems of modern school education: a view from the inside // Pedagogical skills: materials of the VII Intern. scientific. conf. (Moscow, November 2015). - M.: Buki-Vedi

Diachok, N., Chernukha, N., Tokaruk, L., Udovenko, I., Petrova, M. (2020). Practical-oriented concept as a principle of professional education of the future professionals. International Journal of Higher Education, Vol. 9, No. 4, August 2020, pp.272-282, https://doi.org/10.5430/ijhe.v9n4p272

Goletiani, K., Mushkudiani, Z., Gulua, E., Janelidze, N. (2021). Difficulties in managing diversity in Georgian educational organizations. Access to science, business, innovation in digital economy, ACCESS Press, 2(2): 123-137. https://doi.org/10.46656/access.2021.2.2(1)

Khmelnitskaya N.I. (2008) Taxonomy of BLUM as a basis for assessing student learning outcomes // Modern higher school: an innovative aspect, No. 2. 
Kokhaeva E.N. (2014) Formative (formative) assessment. - Astana: AOO "Nazarbayev Intellectual Schools". Center for Excellence

Linde, I., Petrova, M. (2018) The challenges of formalization and modeling of Higher Education Institutions in the 21st century. CBU International conference proceedings 2018: Innovations in Science and Education, 21.-23.03.2018, pp.303-308, https://doi.org/10.12955/cbup.v6.1173

Nenkov, N., Dyachenko, Yu., Petrova, M., Bondarenko, G., Pustovit, V. (2017). Intelligent and Cognitive Technologies in Education of International Economic Relations Students and Human Resource Development in Enterprises: Methodology in Language. European Journal of Sustainable Development, Publisher: European Center of Sustainable Development, ISSN 22395938 (print), ISSN 2239-6101(online), http://www.ecsdev.org/, Rome, Italy, Vol 6, No.4, 2017, pp.353-360, https://doi.org/10.14207/ejsd.2017.v6n4p353

Petrova, M.; Popova, L.; Dejniak, D. (2020). Children's University activities as implementation of the third mission of higher education institution. Strategies for Policy in Science and Education, Volume: 28, Issue: 2, Pages 161-171

Scriabina N.A. A teacher's perspective on the process of implementing the renewal of educational content in the Republic of Kazakhstan. Retrieved from: https://ust.kz/word/statya_vzglyad_ychitelya_na_obnovlennoe_soderjanie_obrazovaniya_v_res pyblike_kazahstan-110105.html

Shuinshina Sh.M., Alpeisov E.A., Akhmetova B.S., Tuyakov E.A., Adamova M.E. (2019) Some issues of modernization of the education system in Kazakhstan // Modern problems of science and education, No. 2

Spivak, Y., Omelchenko, Sv., Petrova, M., Kurinna, Sv., Kurinnyi, I. (2021) Socio-Pedagogical Conditionsof Future Social Specialist Training for Successful Professional Career. International Journal of Higher Education, Vol. 10, No. 4, August 2021, p.1-8, https://doi.org/10.5430/ijhe.v10n4p1

Sushchenko, O., Akhmedova, O., Stryzhak, O. (2021). The use of interactive training technologies in teaching academic disciplines for students of tourism specialities. Access to science, business, innovation in digital economy, ACCESS Press, 2(1): 28-39. https://doi.org/10.46656/access.2021.2.1(3)

Tuzlukova V., Al-Busaidi S., Burns S.L. (2017) Critical thinking in the language classroom: Teacher beliefs and methods // Pertanika J. Soc. Sci. \& Hum, 25 (2)

Updating the content of secondary education: questions and answers (2017) - Astana

Valdmane, L., Zarina, S., Iliško, D., Badjanova, J., Petrova, M. (2020). Empowering of digital and media literacy of primary school teachers in Latvia. EDULEARN20, 12th annual International Conference on Education and New Learning Technologies, 6th - 7th of July, 2020, https://iated.org/edulearn/; Proceedings of EDULEARN20 Conference 6th-7th July 2020, ISBN: 978-84-09-17979-4, ISSN: 2340-1117, pp.4022-4029, DOI:10.21125/edulearn.2020, Publisher: IATED; $10.21125 /$ edulearn.2020.1087

Zagorodnya, A., Chernukha N., Petrova, M. (2020). Contemporary trends of professional training specialists in the economic field at higher education institutions of Poland and Ukraine. Strategies for Policy in Science and Education, ISSN 1314-8575 (Online), ISSN 1310-0270 (Print), Volume: 28, Issue: 3, Pages: 249-260

Zagorodnya, A., Dichek, N., Chobitko, N., Voznyk, M., Honchar, L., Petrova, M. (2020). Professional training of the economic sector specialists at higher education institutions of the Republic of Poland and Ukraine: criteria of comparison. International Journal of Higher Education, Vol. 9, No. 3, June 2020, pp.139-144, https://doi.org/10.5430/ijhe.v9n3p139 